\title{
Pengaruh Program Keselamatan dan Kesehatan Kerja Terhadap Produktivitas Kerja pada Divisi Proyek
}

\author{
Sunarto Urjoyo Purba1, Tatan Sukwika2,* \\ 1,2Program Studi Magister Manajemen, Sekolah Pascasarjana, Universitas Sahid, Jakarta
}

\begin{abstract}
[The effect of occupational safety and health programs on the work productivity in the project division] This study aims to analyze occupational safety programs and productivity, analysis of occupational safety and health programs on the company's and analysis of the effect of occupational safety and health program variables on employee productivity. The study was conducted by analyzing questionnaires from 58 respondents of employees and contractors in the project division. The data analysis method used is statistical analysis description and path analysis. From the analysis carried out, the occupational safety and health factors that have a high influence on employee productivity are health program variables, disease prevention and measurement and monitoring with values of 18.19, 0.62, and 0.80. Implementation of safety programs to project division has been well implemented, health program variables, disease prevention and measurement and monitoring have a significant and positive effect together on productivity, pressure management and accident prevention contribute positively but not significantly to the productivity variable. With the significant influence of safety programs on work productivity, the company continues and improves the implementation of safety and requires all employees and contractors to implement safety and health following safety policies and procedures. Safety programs that have not significantly improved the concept of existing programs.
\end{abstract}

Keywords: occupational safety and health programs, productivity, descriptive statistics, path analysis

\begin{abstract}
ABSTRAK
Penelitian ini bertujuan untuk menganalisis program Keselamatan dan Kesehatan Kerja (K3) dan produktivitas, analisis program K3 terhadap kinerja perusahaan dan analisis pengaruh dari variabel program K3 terhadap produktivitas karyawan. Penelitian dilakukan dengan menganalisis kuesioner dari 58 responden karyawan dan kontraktor pada divisi proyek. Metode analisis data yang digunakan adalah Analisis Statistik deskripsi dan Analisis jalur. Dari hasil analisis yang dilakukan, faktor Keselamatan dan Kesehatan Kerja (K3) yang memiliki pengaruh paling tinggi terhadap produktivitas karyawan adalah variabel program kesehatan, pencegahan penyakit dan pengukuran dan pengawasan dengan nilai $18,19,0,62$, dan 0,80 . Pelakasanaan program keselamatan dan kesehatan kerja di divisi proyek sudah dilaksanakan dengan baik, variabel program kesehatan, pencegahan penyakit dan pengukuran dan pengawasan berpengaruh secara signifikan dan positif secara bersama-sama terhadap produktivitas, Manajemen tekanan dan pencegahan kecelakaan berkontribusi secara positif namun tidak signifikan terhadap varibel produktivitas. Dengan adanya pengaruh program K3 yang signifikan terhadap produktivitas kerja maka perusahaan melanjutkan peningkatan penerapan K3 dan mewajibkan semua karyawan dan kontraktor mengimplementasikan Keselamatan dan Kesehatan Kerja sesuai kebijakan dan prosedur K3. Program K3 yang belum signifikan untuk meningkatkan konsep program yang sudah ada.
\end{abstract}

Kata kunci: program K3, produktivitas, statistik deskriptif, analisis jalur

\begin{tabular}{lll}
\hline${ }^{*}$ Alamat korespondensi & Histori Artikel: & \\
Alamat Afiliasi: Kampus Pascasarjana Usahid Jl. Jendral Sudirman No. 86, & Naskah masuk (received) & $:$ 16-04-2021 \\
Jakarta 10220. & Naskah revisi (revised) & $: 27-05-2021$ \\
E-mail: tatan.swk@gmail.com & Naskah diterima (accepted) & $: 06-06-2021$
\end{tabular}




\section{PENDAHULUAN}

Proyek konstruksi memiliki sifat yang khas, yang mana tempat kerjanya di ruang terbuka yang dipengaruhi jangka waktu pekerjaan terbatas, pekerjaan yang banyak mengeluarkan tenaga, cuaca, menggunakan peralatan kerja yang membahayakan keselamatan dan kesehataan kerja dan menggunakan pekerja yang belum terlatih. Berdasarkan sifat-sifat yang unik tersebut, maka sektor jasa kontruksi mempunyai resiko kecelakaan besar hingga fatal. Untuk mencegah kecelakaan maka suatu Sistem Manajemen Keselamatan dan Kesehatan Kerja yang mengatur dan dapat menjadi. Tinggi rendahnya penerapan K3 perusahaan akan berpengaruh terhadap produktivitas kerja, karena suasana kerja yang aman dan nyaman akan menciptakan kualitas kerja karyawan yang baik untuk tercapainya tujuan. Peningkatan kualitas kehidupan kerja karyawan juga dapat berpengaruh pada peningkatan produktivitas kerja. Kualitas kehidupan kerja merupakan masalah yang patut mendapat perhatian perusahaan. K3 juga berpengaruh terhadap produktivitas kerja. Produktivitas kerja adalah perbandingan output yang dihasilkan dengan input yang dikeluarkan. Apabila perusahaan tidak menerapkan K3 dengan tepat maka produktivitas kerja dan profit perusahaan akan menurun (Purwanti dan Mochammad, 2017).

Untuk mendukung operasional perusahaan tidak terlepas dari kegiatan proyek. Banyak rangkaian tahapan kegiatan, mulai dari tahap rancang bangun, tahap konstruksi, tahap uji coba sampai tahap operasi dan pemeliharaan menjadikan tingkat risiko kecelakaan dan PAK memiliki kemungkinan yang tinggi. Program K3 menjadi aspek yang sangat penting dalam setiap tahapan proyek, agar tercipta lingkungan kerja yang aman, sehat dan berbudaya K3. Masih terdapat kecelakaan kerja dalam kategori kecelakaan ringan hingga sedang. Kecelakaan kerja juga mempengaruhi produktivitas, karena itu kecelakaan kerja harus dilakukan pencegahan kecelakaan yang holistic dan manajemen tekanan comprehensive melalui program K3 yang dikembangkan meningkatkan produktivitas. Produktifitas berkaitan dengan kuantitas, kualitas, ketepatan waktu, tingkat kecelakaan, biaya kompensasi dan lingkungan kerja. Pada perusahaan kadang kala terjadi keterlambatan proyek sehingga tidak memenuhi target selesai secara kuantitas dan tidak memenuhi ketepatan waktu untuk uji coba. Keterlambatan menambah durasi yang akan berpotensi penambahan biaya -biaya. Akibat keterlambatan bedampak pada pekerjaan buru-buru dikejar deadline. Kondisi lain masih kurangnya kesadaran $\mathrm{K} 3$, baik pengusaha maupun tenaga kerja akan arti pentingnya K3. K3 merupakan hambatan yang sering dihadapi dalam perusahaan, sehingga safety cost menjadi pertimbangan untuk pengusaha atau tidak menjadi prioritas. Padahal dalam UU No.1 Tahun 1970 tentang Keselamatan Kerja sudah jelas diatur syarat-syarat K3.

Berdasarkan uraian latar belakang masalah sebelumnya, maka rumusan masalah dalam penelitian ini, adalah bagaimana program pencegahan kecelakaan, pencegahan penyakit, manajemen tekanan, program kesehatan dan pengukuran dan pengawasan, bagaimana produktivitas dalam hal ini kuantitas kerja, kualitas kerja, ketepatan waktu, tingkat kecelakaan dan reputasi, biaya kompensasi dan lingkungan kerja yang aman, bagaimana program keselamatan dan kesehatan kerja terhadap kinerja K3 perusahaan dan bagaimana pengaruh program K3 terhadap produktivitas karyawan. Tujuan penelitian yaitu analisis program pencegahan kecelakaan, pencegahan penyakit, manajemen tekanan, program kesehatan dan pengukuran dan pengawasan, produktivitas dalam hal ini kuantitas kerja, kualitas kerja, ketepatan waktu, tingkat kecekakaan dan reputasi, biaya kompensasi dan lingkunga kerja yang aman, program K3 terhadap kinerja K3 perusahaan dan pengaruh program K3 terhadap produktivitas kerja. Penelitian dibatasi pada program K3 yakni Pencegahan kecelakaan, pencegahan penyakit, manajemen tekanan, kesehatan dan mengukur dan mengawasi, serta yang diteliti adalah karyawan lapangan bagian proyek dalam kesehariannya berhadapan langsung dengan pekerjaan berisiko tinggi yang erat kaitannya dengan $\mathrm{K} 3$, dan semua faktor produktivitas yang telah disebutkan dianggap tetap. 


\section{TINJAUAN LITERATUR}

Menurut PP Nomor 50 Tahun 2012 tentang pelaksanaan Sistem Manajemen Keselamatan dan Kesehatan Kerja (SMK3) adalah bagian dari sistem manajemen perusahaan secara keseluruhan dalam rangka pengendalian risiko yang berkaitan dengan kegiatan kerja guna terciptanya tempat kerja yang aman, efisien dan produktif.

Menurut Permen PUPR No.05/PRT/M/2014 tentang SMK3 konstruksi dapat diterapkan secara konsisten untuk meningkatkan efektifitas perlindungan keselamatan dan kesehatan kerja yang terencana, terukur, terstruktur dan terintegrasi; dapat mencegah dan mengurangi kecelakaan kerja dan penyakit akibat kerja; serta menciptakan tempat kerja yang aman, nyaman dan efisien, untuk mendorong produktifitas. Teori Hameed dan Amjad (2009) Faktor-faktor yang digunakan dalam pengukuran produktivitas adalah: Kuantitas kerja, kualitas kerja, ketepatan waktu.

Penelitian Chind et al. (2012) tingkat kecelakaan, biaya kompensasi, seperti kompensasi biaya dan kerusakan dan lingkungan kerja yang baik. Strategi atau upaya untuk meningkatkan keselamatan dan kesehatan kerja yang efektif dapat dilihat dari 5 (lima) dimensi (Jackson et al., 2011) adalah Pencegahan kecelakan, pencegahan penyakit, manajemen tekanan, program kesehatan, pengukuran dan pengawasan. Kecelakaan kerja adalah suatu kejadian yang tidak diharapkan atau diinginkan yang berkaitan dengan hubungan kerja (Katsuro et al, 2010). Perencanaan K3 yang baik, dimulai dengan melakukan identifikasi bahaya, penilaian resiko, dan penentuan pengendaliannya (Kani, 2013). Proyek konstruksi memiliki sifat yang khas, antara lain tempat kerjanya di ruang terbuka yang dipengaruhi cuaca, jangka waktu pekerjaan terbatas, menggunakan pekerja yang belum terlatih, menggunakan peralatan kerja yang membahayakan keselamatan dan kesehataan kerja dan pekerjaan yang banyak mengeluarkan tenaga. (Pangkey, 2012). Pencegahan kecelakaan kerja yang disebabkan oleh faktor peralatan dan lingkungan kerja dapat dilakukan dengan membuat prosedur kerja standar K3 dan prosedur kerja standar teknis (Messah et al., 2015). Alex et al. (2019) manajemen tekanan juga untuk mengembangkan strategi intervensi yang bertujuan untuk meningkatkan kepatuhan terhadap hukum dan peraturan K3 di industri konstruksi. Unsur Inti Praktik yang direkomendasikan untuk program keselamatan dan kesehatan dalam konstruksi: pengelolaan kepemimpinan, partisipasi pekerja, identifikasi bahaya dan pengendalian risiko, pencegahan bahaya dan control, pendidikan dan latihan, program evaluasi dan perbaikan, komunikasi dan koordinasi untuk karyawan aktif multiemployer lokakarya (Occupational Safety and Health Administration, 2016). Kecelakaan paling banyak jatuh dari ketinggian adalah cedera fatal di industri konstruksi. Untuk mengurangi jatuh dari ketinggian, akses yang aman dan tepi yang aman perlindungan dan penggunaan perancah yang sesuai dengan perlindungan tepi yang baik (Saeed, 2017). Keuntungan penerapan SMK3 mengurangi jumlah cedera pada personel dan operator di tempat kerja melalui pencegahan dan pengendalian tempat kerja bahaya; meminimalkan risiko kecelakaan; dan mengontrol risiko tempat kerja (Choudhry et al., 2008). Menurut Yiu et al. (2019) kinerja K3 adalah bekerja dengan aman lingkungan dioperasikan kegiatan konstruksi, indikasi positif dari performa utama indikator, kualitas yang diinginkan individu, prosedur tepat dan manual, keamanan yang mendukung kepatuhan dan skema insentif. Faktor mempengaruhi kinerja K3: Pengalaman pekerja, perilaku manusia, psikologi, lingkungan alam, lingkungan kerja, faktor insentif dan anggaran proyek, faktor kebijakan dan prosedur, rencana $\mathrm{K} 3$, inspeksi, rekam dan audit, training $\mathrm{K} 3$, komitmen manajemen, komunikasi dan umpan balik, serta keterlibatan karyawan (El-Nagar et al., 2015). Konstruksi adalah salah satu industri yang paling tidak aman karena sifatnya yang unik. Proyek dilakukan di tingkat dan kompleksitas yang meningkat, dan kecelakaan memimpin untuk dampak yang lebih besar, industri konstruksi selalu diiringi oleh banyak kecelakaan dan kematian (Tingshen et al., 2018). Penelitian ini berpendapat bahwa semakin baik program K3 maka produktivitas karyawan akan meningkat, dengan demikian hipotesis yang diajukan adalah sebagai berikut:

$H_{1} \leftleftarrows$ Terdapat pengaruh variabel program K3 terhadap variabel Produktivitas kerja 


\section{METODE}

Target populasi penelitian seluruh pekerja divisi proyek yang berjumlah 67 orang yang ada di divisi proyek. Teknik pengambilan sampel yang digunakan adalah simple random sampling, yaitu pengambilan sampel dari anggota populasi dengan menggunakan acak tanpa memperhatikan strata dalam anggota populasi. Ukuran sampel dilakukan dengan menggunakan rumus Slovin dengan tingkat prepesisi 5\%, tingkat kepercayaan 95\% sehingga sampe/ $n=58$ responden. Instrumen yang digunakan adalah lembar checklist kuesioner yang dibagikan. Untuk memperoleh instrumen yang handal, digunakan uji validitas dan reliabilitas. metode pengumpulan data adalah penelitian kepustakaan, lapangan, observasi dan kuesioner. Tipe skala yang digunakan untuk mengukur variabel pada penelitian ini adalah skala ordinal, dan skala nominal dibatasi untuk data responden. Penggunaan skala ordinal untuk mengetahui seberapa kuat responden setuju atau tidak setuju dengan pertanyaan pada kuesioner melalui skala litkert.

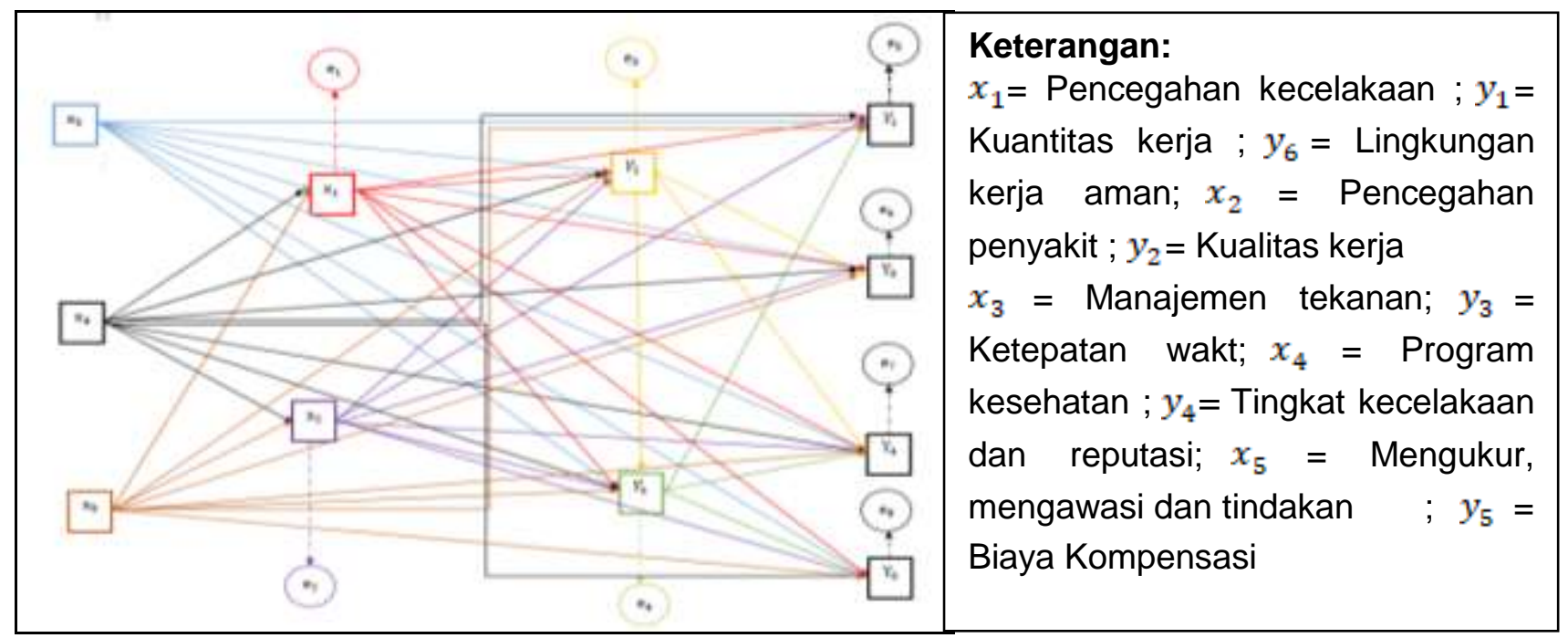

Gambar 1. Model diagram jalur struktural kausal

Dalam penelitian terdiri dari dua variabel yaitu variabel program K3 dan variabel produktivitas kerja. Variabel bebas Program keselamatan dan kesehatan kerja terdiri dari pencegahan kecelakaan, pencegahan penyakit, manajemen tekanan, program kesehatan, mengukur dan mengawasi. Sedangkan variabel terikat produktivitas kerja terdiri dari kuantitas kerja, kualitas kerja, ketepatan waktu, tingkat kecelakaan dan reputasi, biaya kompensasi dan lingkungan kerja aman.

Analisis data menggunakan Analisis deskriptif dan analisis jalur dengan alat Microsoft Excel dan SPSS. Langkah-langkah analisis jalur yaitu merancang diagram jalur dan persamaan substruktural dan sesuai hipotesis, model sub struktural dan persamaan struktural akan dihitung koefisien jalur dengan SPSS, pengujian hipotesis, koefisien determinasi $\left(R^{2}\right)$, besar pengaruh diluar penelitian $e=\sqrt{1-R^{2}}$, pengaruh parsial yaitu pengaruh langsung dan pengaruh tidak langsung, Interpretasi model yaitu membandingkan teori dan hasil analisis dari perhitungan SPSS.Model diagram jalur struktural kausal antara variabel bebas, variabel intervening dan variabel terikat dapat dilihat pada gambar 1. 


\section{HASIL DAN PEMBAHASAN}

\section{Hasil Uji Validitas dan Reliabilitas}

Uji validitas pre test yang yang dilakukan kepada 30 orang responden. Dari Tabel 1 di atas dapat diketahui bahwa semua variabel untuk nilai KMO dan nilai Barlett's Test of Sphericity Valid. Cronback's Alpha digunakan untuk uji reliabilitas. Konstruk yang dianggap reliabel adalah lebih besar dari 0.6.

Tabel 1. Nilai KMO Measure Sampling Adequacy Barlett's Test of Sphericity pada pre test.

\begin{tabular}{lllcl}
\hline Kode & \multicolumn{1}{c}{ Dimensi variabel } & KMO & Barlett's Test & Keterangan \\
\hline $\mathrm{x}_{1}$ & Pencegahan kecelakaan & .760 & .000 & Valid \\
\hline $\mathrm{x}_{2}$ & Pencegahan penyakit & .858 & .000 & Valid \\
\hline $\mathrm{x}_{3}$ & Manajemen tekanan & .876 & .000 & Valid \\
\hline $\mathrm{x}_{4}$ & Program kesehatan & .823 & .000 & Valid \\
\hline $\mathrm{x}_{5}$ & Mengukur dan mengawasi & .819 & .000 & Valid \\
\hline $\mathrm{Y}_{1}$ & Kuantatitas kerja & .791 & .000 & Valid \\
\hline $\mathrm{Y}_{2}$ & Kualitas kerja & .877 & .000 & Valid \\
\hline $\mathrm{Y}_{3}$ & Ketepatan waktu & .742 & .000 & Valid \\
\hline $\mathrm{Y}_{4}$ & Tingkat Kecelakaan \& reputasi & .500 & .000 & Valid \\
\hline $\mathrm{Y}_{5}$ & Biaya kompensasi & .500 & .000 & Valid \\
\hline $\mathrm{Y}_{6}$ & Lingkungan kerja yang aman & .500 & .000 & Valid \\
\hline
\end{tabular}

Hasil reliabilitas dapat dilihat pada Tabel 2. Pada Tabel 2 dan Tabel 3 menunjukkan seluruh dimensi dari variabel program K3 dan produktivitas kerja memiliki reliabilitas yang tinggi, yaitu lebih besar dari 0.600

Tabel 2. Reliabilitas dimensi program K3

\begin{tabular}{clc}
\hline No & \multicolumn{1}{c}{ Dimensi Program K3 } & Cronback's Alpha \\
\hline 1 & Pencegahan kecelakaan & .972 \\
\hline 2 & Pencegahan penyakit & .970 \\
\hline 3 & Manajemen tekanan & .953 \\
\hline 4 & Program kesehatan & .943 \\
\hline 5 & Mengukur dan mengawasi & .970 \\
\hline
\end{tabular}

Tabel 3. Reliabilitas dimensi produktivitas kerja

\begin{tabular}{clc}
\hline No & \multicolumn{1}{c}{ Dimensi produktivitas kerja } & Cronback's Alpha \\
\hline 1 & Kuantitas Kerja & .959 \\
\hline 2 & Kualitas Kerja & .951 \\
\hline 3 & Ketepatan waktu & .938 \\
\hline 4 & Tingkat Kecelakaan \& reputasi & .916 \\
\hline 5 & Biaya Kompensasi & .890 \\
\hline 6 & Lingkungan kerja yang Aman & .829 \\
\hline
\end{tabular}

\section{Hasil Analisis Deskriptif}

Berdasarkan Tabel 4, 5, 6, 7 \& 8 dapat diketahui bahwa variabel pencegahan kecelakaan, pencegahan penyakit, manajemen tekanan, program kesehatan dan pengukuran dan pengawasan 
memiliki nilai mean sebesar 4,24, 4,31, 4,35, 4,29, dan 4,35 dengan standar deviasi 0,8, 0,72, 0,64, 0,65 dan 0,66. Hasil dari rata-rata variabel Mengukur, mengawasi dan tindakan tersebut termasuk pada kategori tinggi yang berarti pelaksanaan keselamatan dan kesehatan kerja yang ada sudah baik. Persentasi standar deviasi variabel pencegahan kecelakaan, pencegahan penyakit, manajemen tekanan, program kesehatan dan pengukuran dan pengawasan masingmasing $18.4 \%, 16,7 \%, 14,7 \%, 14,7 \%$ dan $15.2 \%$ dari nilai mean. Jika nilai standar deviasi di bawah $20 \%$, hal ini menandakan bahwa sebagian besar responden didalam menjawab pernyataan dalam variabel penelitian ini dengan jawaban yang relatif sama.

Tabel 4. Hasil analisis deskriptif variabel pencegahan kecelakaan

\begin{tabular}{lcccccc}
\hline Item & Jumlah Responden (n-1) & Mean & Varians & SD & Min & Max \\
\hline $\mathrm{X} 11$ & 57 & 4.12 & 0.51 & 0.71 & 3 & 5 \\
\hline $\mathrm{X} 12$ & 57 & 4.14 & 0.53 & 0.73 & 3 & 5 \\
\hline $\mathrm{X} 13$ & 57 & 4.26 & 0.62 & 0.79 & 3 & 5 \\
\hline $\mathrm{X} 14$ & 57 & 4.26 & 0.58 & 0.76 & 3 & 5 \\
\hline $\mathrm{X} 15$ & 4.14 & 0.72 & 0.85 & 3 & 5 \\
\hline $\mathrm{X} 16$ & 57 & 4.44 & 0.66 & 0.81 & 3 & 5 \\
\hline $\mathrm{X} 17$ & 57 & 4.23 & 0.56 & 0.75 & 3 & 5 \\
\hline $\mathrm{X} 18$ & 57 & 4.46 & 0.67 & 0.82 & 3 & 5 \\
\hline $\mathrm{X} 19$ & 57 & 4.19 & 0.74 & 0.86 & 3 & 5 \\
\hline $\mathrm{X} 20$ & 57 & 4.16 & 0.51 & 0.71 & 3 & 5 \\
\hline \multicolumn{2}{r}{ Pencegahan kecelakaan $(\mathrm{X} 1)$} & 4.24 & 0.61 & 0.78 & 3 & 5 \\
\hline
\end{tabular}

Tabel 5. Hasil analisis deskriptif variabel pencegahan penyakit

\begin{tabular}{ccccccc}
\hline Item & Jumlah Responden (n-1) & Mean & Var & SD & Min & Max \\
\hline $\mathrm{X} 21$ & 57 & 4.19 & 0.50 & 0.71 & 3 & 5 \\
\hline $\mathrm{X} 22$ & 57 & 4.23 & 0.49 & 0.70 & 3 & 5 \\
\hline $\mathrm{X} 23$ & 57 & 4.33 & 0.59 & 0.77 & 3 & 5 \\
\hline $\mathrm{X} 24$ & 4.26 & 0.48 & 0.69 & 3 & 5 \\
\hline $\mathrm{X} 25$ & 57 & 4.28 & 0.58 & 0.76 & 3 & 5 \\
\hline $\mathrm{X} 26$ & 57 & 4.44 & 0.56 & 0.75 & 3 & 5 \\
\hline $\mathrm{X} 27$ & 57 & 4.21 & 0.44 & 0.66 & 3 & 5 \\
\hline $\mathrm{X} 28$ & 57 & 4.53 & 0.57 & 0.76 & 3 & 5 \\
\hline & 57 & 4.31 & 0.53 & 0.72 & 3 & 5 \\
\hline
\end{tabular}

Tabel 6. Hasil analisis deskriptif variabel manajemen tekanan

\begin{tabular}{ccccccc}
\hline Item & \multirow{2}{*}{ Jumlah Responden (n-1) } & Mean & Var & SD & Min & Max \\
\hline X29 & 57 & 4.28 & 0.42 & 0.65 & 3 & 5 \\
\hline X30 & 57 & 4.37 & 0.43 & 0.65 & 3 & 5 \\
\hline X31 & 57 & 4.39 & 0.47 & 0.68 & 3 & 5 \\
\hline X32 & 57 & 4.35 & 0.35 & 0.59 & 3 & 5 \\
\hline X33 & 4.35 & 0.41 & 0.64 & 3 & 5 \\
\hline & 57 & 4.35 & 0.42 & 0.64 & 3 & 5 \\
\hline
\end{tabular}


Tabel 7. Hasil analisis deskriptif variabel program kesehatan

\begin{tabular}{ccccccc}
\hline \multirow{2}{*}{ Item } & Responden $(\mathbf{n}-\mathbf{1})$ & Mean & Var & SD & Min & Max \\
& & & & & & \\
\hline X34 & 57 & 4.19 & 0.39 & 0.63 & 3 & 5 \\
\hline X35 & 57 & 4.28 & 0.45 & 0.67 & 3 & 5 \\
\hline X36 & 57 & 4.33 & 0.48 & 0.69 & 3 & 5 \\
\hline X37 & 57 & 4.33 & 0.38 & 0.61 & 3 & 5 \\
\hline \multicolumn{2}{r}{ Program kesehatan } & 4.29 & 0.43 & 0.65 & 3 & 5 \\
\hline
\end{tabular}

Tabel 8. Hasil analisis deskriptif variabel mengukur, mengawasi dan tindakan

\begin{tabular}{|c|c|c|c|c|c|c|}
\hline Item & Jumlah Responden (n-1) & Mean & Var & SD & Min & Max \\
\hline $\mathrm{X} 38$ & 57 & 4.35 & 0.42 & 0.65 & 3 & 5 \\
\hline X39 & 57 & 4.30 & 0.46 & 0.68 & 3 & 5 \\
\hline $\mathrm{X} 40$ & 57 & 4.32 & 0.51 & 0.71 & 3 & 5 \\
\hline $\mathrm{X} 41$ & 57 & 4.33 & 0.41 & 0.64 & 3 & 5 \\
\hline $\mathrm{X} 42$ & 57 & 4.28 & 0.45 & 0.67 & 3 & 5 \\
\hline $\mathrm{X} 43$ & 57 & 4.51 & 0.47 & 0.68 & 3 & 5 \\
\hline $\mathrm{X} 44$ & 57 & 4.21 & 0.34 & 0.58 & 3 & 5 \\
\hline $\mathrm{X} 45$ & 57 & 4.54 & 0.47 & 0.69 & 3 & 5 \\
\hline $\mathrm{X} 46$ & 57 & 4.28 & 0.49 & 0.70 & 3 & 5 \\
\hline$\overline{X 47}$ & 57 & 4.33 & 0.41 & 0.64 & 3 & 5 \\
\hline \multicolumn{2}{|c|}{ Mengukur, Mengawasi dan Tindakan } & 4.35 & 0.44 & 0.66 & 3 & 5 \\
\hline
\end{tabular}

Berdasarkan Tabel 9, 10, 11, 12, 13 \& 14 dapat diketahui bahwa variabel kuantitas kerja, kualitas kerja, ketepatan waktu, tingkat kecelakaan kerja \& reputasi, biaya kompensasi lingkungan kerja aman nilai mean masing-masing sebesar 4,30, 4,35, 4,37, 4,23, 4,34 dan 4,37 dengan standar deviasi $0,70,0,65,0,66,0,71,0,66$ dan 0,74 . Hasil dari rata-rata variabel produktivitas kerja tersebut termasuk pada kategori tinggi yang berarti pelaksanaan keselamatan dan kesehatan kerja yang ada sudah baik. Presentase standar deviasi variabel kuantitas kerja, kualitas kerja, ketepatan waktu, tingkat kecelakaan kerja \& reputasi, biaya kompensasi lingkungan kerja aman $16,2 \%, 14,9 \%, 15,1 \%, 16,8 \%, 15,2 \%$ dan $16,9 \%$ dari nilai mean masing-masing. Jika nilai standar deviasi di bawah $20 \%$, hal ini menandakan bahwa sebagian besar responden didalam menjawab pernyataan dalam variabel penelitian ini dengan jawaban yang relatif sama.

Tabel 9. Hasil analisis deskriptif variabel kuantitas kerja

\begin{tabular}{ccccccc}
\hline Item & Jumlah Responden $(\mathbf{n}-\mathbf{1})$ & Mean & Var & SD & Min & Max \\
\hline $\mathrm{Y} 11$ & 57 & 4.23 & 0.52 & 0.72 & 3 & 5 \\
\hline $\mathrm{Y} 12$ & 57 & 4.49 & 0.53 & 0.73 & 3 & 5 \\
\hline $\mathrm{Y} 13$ & 4.19 & 0.39 & 0.63 & 3 & 5 \\
\hline $\mathrm{Y} 14$ & 4.51 & 0.54 & 0.73 & 3 & 5 \\
\hline $\mathrm{Y} 15$ & 57 & 4.25 & 0.56 & 0.75 & 3 & 5 \\
\hline $\mathrm{Y} 16$ & 57 & 4.19 & 0.39 & 0.63 & 3 & 5 \\
\hline & 57 & 4.31 & 0.49 & 0.70 & 3 & 5 \\
\hline
\end{tabular}


Tabel 10. Hasil analisis deskriptif variabel kualitas kerja

\begin{tabular}{ccccccc}
\hline Item & Jumlah Responden $(\mathbf{n}-\mathbf{1})$ & Mean & Var & SD & Min & Max \\
\hline Y17 & 57 & 4.35 & 0.38 & 0.62 & 3 & 5 \\
\hline Y18 & 57 & 4.28 & 0.45 & 0.67 & 3 & 5 \\
\hline Y19 & 57 & 4.33 & 0.48 & 0.69 & 3 & 5 \\
\hline Y20 & 57 & 4.33 & 0.38 & 0.61 & 3 & 5 \\
\hline Y21 & 57 & 4.28 & 0.45 & 0.67 & 3 & 5 \\
\hline Y22 & 57 & 4.54 & 0.43 & 0.66 & 3 & 5 \\
\hline & Kualitas Kerja & 4.35 & 0.43 & 0.65 & 3 & 5 \\
\hline
\end{tabular}

Tabel 11. Hasil analisis deskriptif variabel ketepatan waktu

\begin{tabular}{ccccccc}
\hline \multirow{2}{*}{ Item } & \multirow{2}{*}{ Jumlah Responden (n-1) } & Mean & Var & SD & Min & Max \\
\hline Y23 & 57 & 4.33 & 0.48 & 0.69 & 3 & 5 \\
\hline Y24 & 57 & 4.33 & 0.38 & 0.61 & 3 & 5 \\
\hline Y25 & 57 & 4.28 & 0.45 & 0.67 & 3 & 5 \\
\hline Y26 & 57 & 4.54 & 0.43 & 0.66 & 3 & 5 \\
\hline & Ketepatan Waktu & 4.37 & 0.44 & 0.66 & 3 & 5 \\
\hline
\end{tabular}

Tabel 12. Hasil analisis deskriptif variabel tingkat kecelakaan \& reputasi

\begin{tabular}{ccccccc}
\hline \multirow{2}{*}{ Item } & \multirow{2}{*}{ Jumlah Responden (n-1) } & Mean & Var & SD & Min & Max \\
\hline Y27 & 57 & 4.19 & 0.53 & 0.73 & 3 & 5 \\
\hline Y28 & 57 & 4.26 & 0.48 & 0.69 & 3 & 5 \\
\hline \multicolumn{2}{c}{ Tingkat Kecelakaan \& reputasi } & 4.23 & 0.51 & 0.71 & 3 & 5 \\
\hline
\end{tabular}

Tabel 13. Hasil Analisis Deskriptif Variabel Biaya Kompensasi

\begin{tabular}{ccccccc}
\hline Item & Jumlah Responden $(\mathbf{n}-\mathbf{1})$ & Mean & Var & SD & Min & Max \\
\hline Y29 & 57 & 4.32 & 0.47 & 0.69 & 3 & 5 \\
\hline Y30 & 57 & 4.37 & 0.39 & 0.63 & 3 & 5 \\
\hline & Biaya Kompensasi & 4.34 & 0.43 & 0.66 & 3 & 5 \\
\hline
\end{tabular}

Tabel 14. Hasil analisis deskriptif variabel lingkungan kerja yang aman

\begin{tabular}{ccccccc}
\hline Item & Jumlah Responden (n-1) & Mean & Var & SD & Min & Max \\
\hline Y31 & 57 & 4.28 & 0.56 & 0.75 & 3 & 5 \\
\hline Y32 & 57 & 4.46 & 0.53 & 0.73 & 3 & 5 \\
\hline \multicolumn{2}{c}{ Lingkungan kerja yang Aman } & 4.37 & 0.54 & 0.74 & 3 & 5 \\
\hline
\end{tabular}

\section{Hasil Analisis Jalur}

Berdasarkan hasil penelitian diperoleh nilai Sig. $=0,000$ atau $<0,05$ maka Ho ditolak dan $\mathrm{Ha}$ diterima. Dengan demikian dapat ditarik kesimpulan bahwa kualitas kerja, dipengaruhi oleh pencegahan kecelakaan, pencegahan penyakit, manajemen tekanan, program kesehatan dan pengukuran dan pengawasan secara simultan dan signifikan sebesar $91,4 \%$ dan sisanya sebesar $8,6 \%$ dipengaruhi oleh variabel-variabel lain di luar penelitian ini. 
Table 15. Rangkuman hasil koefisien jalur sub-struktur 1

\begin{tabular}{|c|c|c|c|c|c|}
\hline Peng. Antar Variabel & Koef. Jalur & Nilai Sig. & Hasil Pengujian & KD & Var. Lain \\
\hline$X_{1}$ terhadap variabel $Y_{2}$ & 0,038 & 0,429 & Tidak Signifikan & \multirow{5}{*}{$\begin{array}{l}0,914= \\
91,4 \%\end{array}$} & \multirow{5}{*}{0,29} \\
\hline$X_{2}$ terhadap variabel $Y_{2}$ & 0,034 & 0,594 & Tidak Signifikan & & \\
\hline$X_{3}$ terhadap variabel $Y_{2}$ & $-0,044$ & 0,320 & Tidak Signifikan & & \\
\hline$X_{4}$ terhadap variabel $Y_{2}$ & 0,925 & 0,000 & Signifikan & & \\
\hline$X_{5}$ terhadap variabel $Y_{2}$ & 0,019 & 0,743 & Tidak Signifikan & & \\
\hline
\end{tabular}

Pengaruh pencegahan kecelakaan, pencegahan penyakit, manajemen tekanan, program kesehatan, dan penguran \& pengawasan terhadap kualitas kerja

Tabel 16. Rangkuman hasil koefisien jalur sub-struktur 2

\begin{tabular}{|c|c|c|c|c|c|}
\hline Peng. Antar Variabel & Koef.Jalur & NilaiSig. & Hasil Pengujian & KD & Var.Lain \\
\hline$X_{1}$ terhadap variabel $Y_{6}$ & $-0,271$ & 0,000 & Pengaruh Signifikan & \multirow{6}{*}{$\begin{array}{l}0,852= \\
85,2 \%\end{array}$} & \multirow{6}{*}{0,38} \\
\hline$X_{2}$ terhadap variabel $Y_{6}$ & 0,454 & 0,000 & Pengaruh Signifikan & & \\
\hline$X_{3}$ terhadap variabel $Y_{6}$ & 0,057 & 0,330 & Tidak Signifikan & & \\
\hline$X_{4}$ terhadap variabel $Y_{2}$ & $-0,441$ & 0,019 & Pengaruh Signifikan & & \\
\hline$X_{5}$ terhadap variabel $Y_{6}$ & 0,446 & 0,000 & Pengaruh Signifikan & & \\
\hline$y_{2}$ terhadap variabelY $Y_{6}$ & 0,608 & 0,002 & Pengaruh Signifikan & & \\
\hline
\end{tabular}

Pengaruh pencegahan kecelakaan, pencegahan penyakit, manajemen tekanan, program kesehatan, dan pengukuran \& pengawasan terhadap lingkungan kerja aman

Berdasarkan hasil penelitian Sig. $=0,000$ atau $<0,05$ maka Ho ditolak dan Ha diterima lingkungan kerja yang aman dipengaruhi oleh pencegahan kecelakaan, pencegahan penyakit, manajemen tekanan, program kesehatan dan mengukur, mengawasi dan tindakan secara simultan dan signifikan sebesar $85 \%$ dan sisanya sebesar $14,8 \%$ dipengaruhi oleh variabelvariabel lain di luar penelitian ini.

Tabel 17. Rangkuman hasil koefisien jalur sub-struktur 3

\begin{tabular}{|c|c|c|c|c|c|}
\hline Peng. Antar Variabel & Koefisien Jalur & NilaiSig. & Hasil Pengujian & KD & Var. Lain \\
\hline$X_{1}$ terhadap variabel $Y_{1}$ & 0,063 & 0,563 & TidakSignifikan & \multirow{6}{*}{$\begin{array}{c}0,66 \\
0=66 \\
\%\end{array}$} & \multirow{6}{*}{0,58} \\
\hline$X_{2}$ terhadap variabel $Y_{1}$ & $-0,163$ & 0,300 & TidakSignifikan & & \\
\hline$X_{3}$ terhadap variabel $Y_{1}$ & $-0,005$ & 0,954 & TidakSignifikan & & \\
\hline$X_{4}$ terhadap variabel $Y_{1}$ & $-0,114$ & 0,280 & TidakSignifikan & & \\
\hline$X_{5}$ terhadap variabel $Y_{1}$ & 0,798 & 0,000 & Pengaruh Signifikan & & \\
\hline$Y_{6}$ terhadap variabel $Y_{1}$ & 0,182 & 0,349 & TidakSignifikan & & \\
\hline
\end{tabular}

Pengaruh pencegahan kecelakaan, pencegahan penyakit, manajemen tekanan, program kesehatan, pengukuran \& pengawasan dan lingkungan kerja aman terhadap kuantitas kerja

Berdasarkan hasil penelitian Sig. $=0,000$ atau $<0,05$ maka Ho ditolak dan Ha diterima. Kuantitas Kerja, dipengaruhi oleh Pencegahan Kecelakaan, Pencegahan Penyakit, Manajemen tekanan, Program Kesehatan dan Mengukur, mengawasi dan tindakan dan Lingkungan Kerja yang 
aman, secara simultan dan signifikan sebesar $66 \%$ dan sisanya sebesar $38 \%$ dipengaruhi oleh variabel-variabel lain di luar penelitian ini.

Tabel 18. Rangkuman hasil koefisien jalur sub-struktur 4

\begin{tabular}{|c|c|c|c|c|c|}
\hline Peng. Antar Variabel & Koef. Jalur & NilaiSig. & Hasil Pengujian & KD & $\begin{array}{l}\text { Var. } \\
\text { Lain }\end{array}$ \\
\hline$X_{1}$ terhadap variabel $y_{3}$ & 0,027 & 0,237 & Tidak Signifikan & \multirow{6}{*}{$\begin{array}{l}0,981= \\
98,1 \%\end{array}$} & \multirow{6}{*}{0,13} \\
\hline$X_{2}$ terhadap variabel $y_{3}$ & 0,028 & 0,345 & Tidak Signifikan & & \\
\hline$X_{3}$ terhadap variabel $y_{3}$ & 0,001 & 0,946 & Tidak Signifikan & & \\
\hline$X_{4}$ terhadap variabel $y_{3}$ & $-0,208$ & 0,002 & Pengaruh Signifikan & & \\
\hline$X_{5}$ terhadap variabel $y_{3}$ & $-0,061$ & 0,032 & Pengaruh Signifikan & & \\
\hline$Y_{2}$ terhadap variabel $y_{3}$ & 1.180 & 0,000 & Pengaruh Signifikan & & \\
\hline
\end{tabular}

Pengaruh pencegahan kecelakaan, pencegahan penyakit, manajemen tekanan, program kesehatan, pengukuran\& pengawasan dan kualitas kerja terhadap ketepatan waktu

Berdasarkan hasil penelitian Sig. = 0,000 atau < 0,05 maka Ho ditolak dan Ha diterima. Ketepatan Waktu, dipengaruhi oleh Pencegahan Kecelakaan, Pencegahan Penyakit, Manajemen tekanan, Program Kesehatan, Mengukur, mengawasi dan tindakan dan Kualitas Kerja secara simultan dan signifikan sebesar $98,1 \%$ dan sisanya sebesar $1,9 \%$ dipengaruhi oleh variabel- lain di luar penelitian ini.

Tabel 19. Rangkuman hasil koefisien jalur sub-struktur 5

\begin{tabular}{|c|c|c|c|c|c|}
\hline Peng. Antar Variabel & Koef. Jalur & Sig. & Hasil Pengujian & KD & $\begin{array}{l}\text { Var. } \\
\text { Lain }\end{array}$ \\
\hline$X_{1}$ terhadap variabel $y_{4}$ & $-0,227$ & .162 & Tidak Signifikan & \multirow{7}{*}{$\begin{array}{c}0,330=3 \\
3 \%\end{array}$} & \multirow{7}{*}{0,81} \\
\hline$X_{2}$ terhadap variabel $y_{4}$ & 0,625 & .008 & Pengaruh Signifikan & & \\
\hline$X_{3}$ terhadap variabel $y_{4}$ & 0,119 & .351 & Tidak Signifikan & & \\
\hline$X_{4}$ terhadap variabel $y_{3}$ & 0,096 & .818 & Tidak Signifikan & & \\
\hline$X_{5}$ terhadap variabel $y_{4}$ & 0,211 & .331 & Tidak Signifikan & & \\
\hline$Y_{2}$ terhadap variabel $y_{4}$ & 0,301 & .492 & Tidak Signifikan & & \\
\hline$Y_{6}$ terhadap variabel $y_{4}$ & 0,593 & 054 & Tidak Signifikan & & \\
\hline
\end{tabular}

Pengaruh pencegahan kecelakaan, pencegahan penyakit, manajemen tekanan, kesehatan \& pengukuran pengawasan, kualitas kerja dan lingkungan aman terhadap tingkat kecelakaan

Berdasarkan hasil penelitian Sig. $=0,000$ atau $<0,05$ maka Ho ditolak dan Ha diterima. Tingkat Kecelakaan dan Reputasi, dipengaruhi oleh Pencegahan Kecelakaan, Pencegahan Penyakit, Manajemen tekanan, Program Kesehatan, Mengukur, mengawasi dan tindakan, Kualitas Kerja dan Lingkungan Kerja yang aman secara simultan dan signifikan sebesar $33 \%$ dan sisanya sebesar $66 \%$ dipengaruhi oleh variabel-variabel lain di luar penelitian ini. 


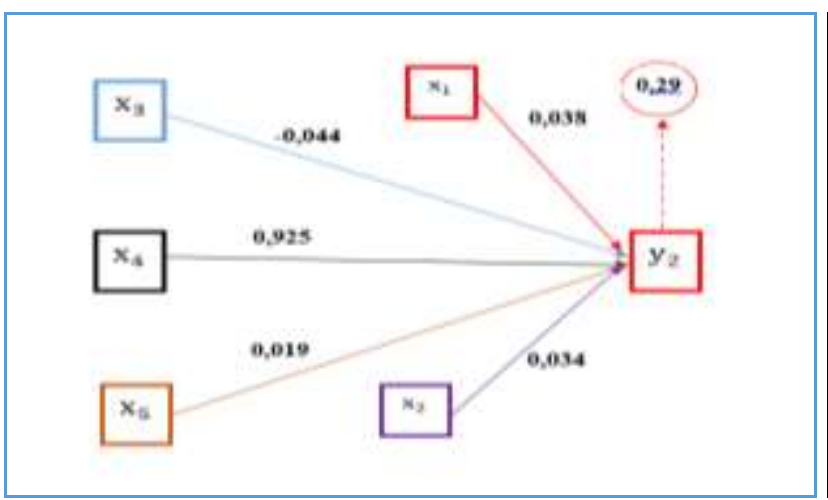

(1)

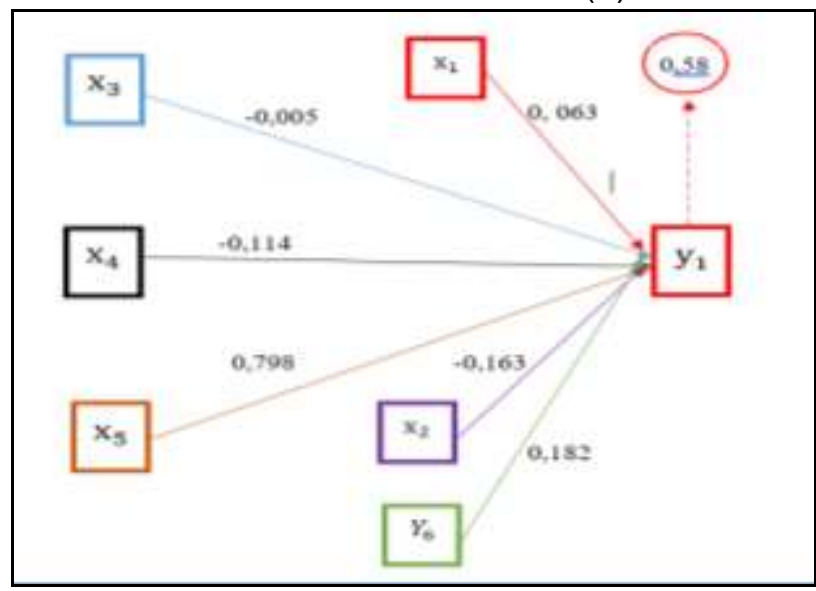

(3)

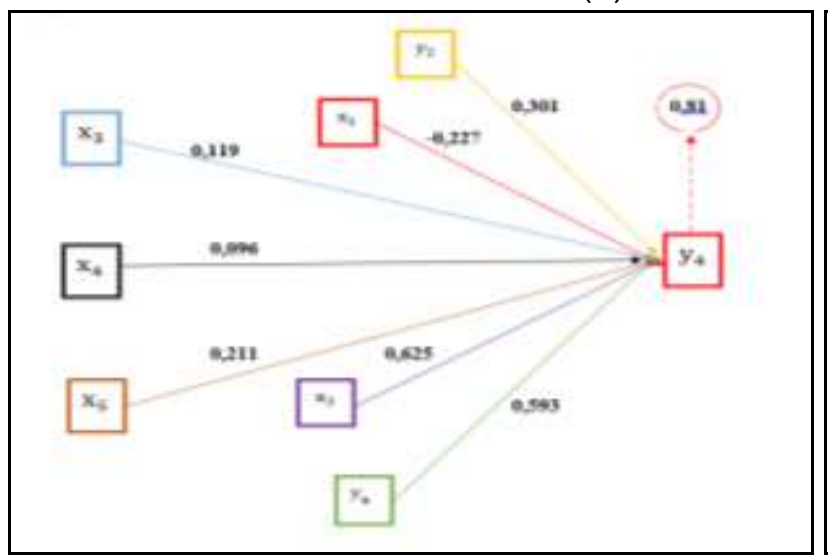

(5)

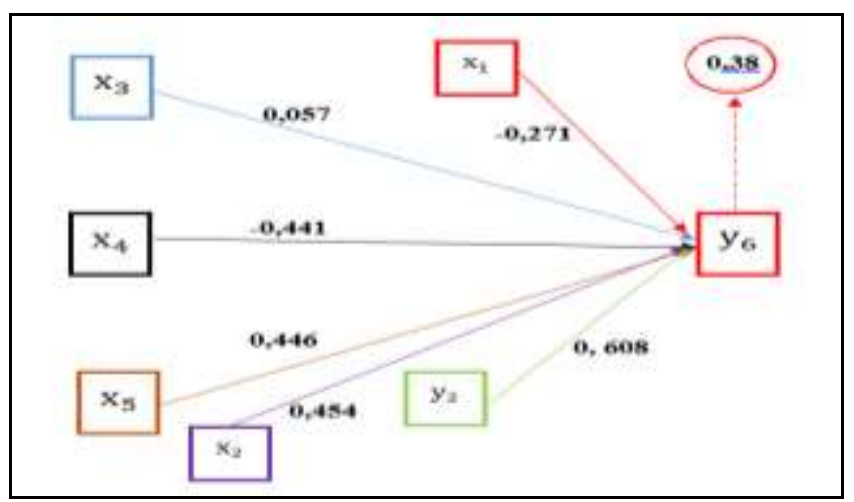

(2)

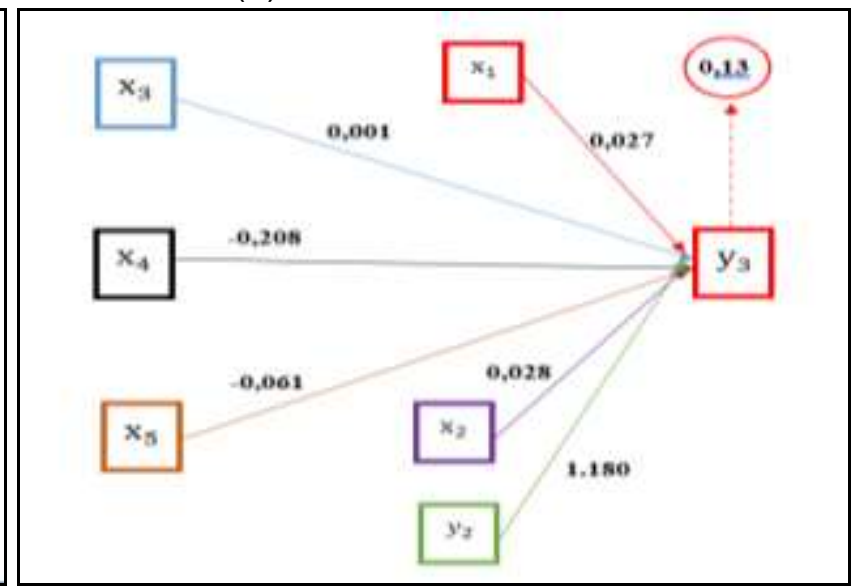

(4)

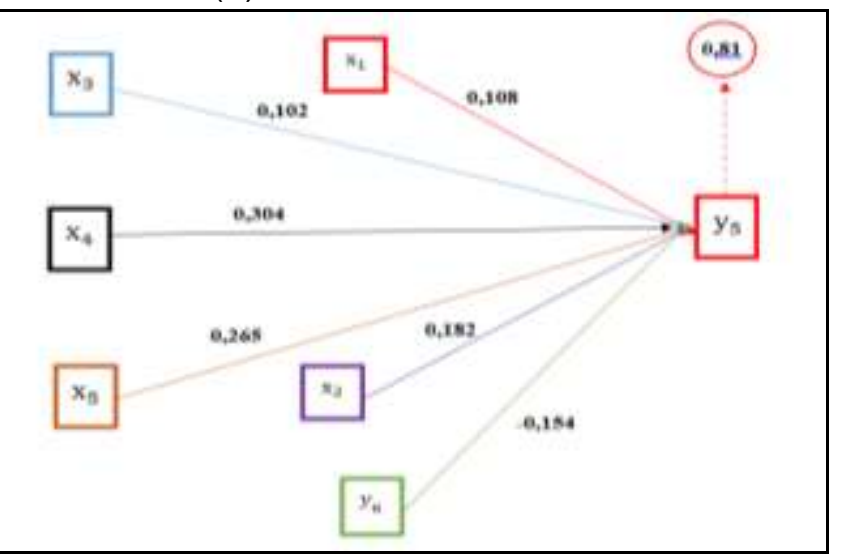

(6)

Gambar 3. Diagram jalur sub-struktur (1), (2), (3), (4), (5) dan (6).

Tabel 20. Rangkuman hasil koefisien jalur sub-struktur 6

\begin{tabular}{|c|c|c|c|c|c|}
\hline Pengaruh Antar Variabel & Koefisien Jalur & Nilai Sig. & Hasil & KD & Var. Lain \\
\hline$X_{1}$ terhadap variabel $y_{5}$ & 0,108 & 0,476 & Tidak Signifikan & \multirow{6}{*}{$\begin{array}{l}0,339= \\
33,9 \%\end{array}$} & \multirow{6}{*}{0,81} \\
\hline$X_{2}$ terhadap variabel $y_{5}$ & 0,182 & 0,405 & Tidak Signifikan & & \\
\hline$X_{3}$ terhadap variabel $y_{5}$ & 0,102 & 0,407 & Tidak Signifikan & & \\
\hline$X_{4}$ terhadap variabel $y_{5}$ & 0,304 & 0,042 & Pengaruh Signifikan & & \\
\hline$X_{5}$ terhadap variabel $y_{5}$ & 0,265 & 0,203 & Tidak Signifikan & & \\
\hline$Y_{6}$ terhadap variabel $y_{5}$ & $-0,154$ & 0,570 & Tidak Signifikan & & \\
\hline
\end{tabular}

Pengaruh pencegahan kecelakaan, pencegahan penyakit, manajemen tekanan, kesehatan, pengukuran \& pengawasan dan lingkungan kerja aman terhadap biaya kompensasi 
Berdasarkan hasil penelitian Sig. $=0,001$ atau $<0,05$ maka Ho ditolak dan Ha diterima. Biaya Kompensasi $\left(Y_{5}\right)$, dipengaruhi oleh Pencegahan Kecelakaan $\left(\mathrm{x}_{1}\right)$, Pencegahan Penyakit $\left(\mathrm{x}_{2}\right)$, Manajemen tekanan $\left(\mathrm{x}_{3}\right)$, Program Kesehatan $\left(\mathrm{x}_{4}\right)$ dan Mengukur, mengawasi dan tindakan $\left(\mathrm{x}_{5}\right)$ dan Lingkungan Kerja yang aman $\left(Y_{6}\right)$, secara simultan dan signifikan sebesar $33,9 \%$ dan sisanya sebesar $66,1 \%$ dipengaruhi oleh variabel-variabel lain di luar penelitian ini. Chinda et al. (2012) Biaya kompensasi budaya keselamatan yang positif mengarah pada pengurangan biaya kecelakaan yang ditanggung organisasi, seperti kompensasi biaya dan kerusakan. Dalam hal ini terbukti bahwa dengan adanya program K3 maka kecelakaan berkurang dan mengurangi biaya kompensasai dalam hal ini kerusakan alat, kehilangan jam kerja, dan aspek sosial lainnya.

\section{KESIMPULAN}

Pelakasanaan program K3 dan produktivitas kerja sudah dilaksanakan dengan baik, meskipun dalam praktik dilapangan masih terdapat kecelakaan kerja ringan hingga sedang. Nilai mean dari masing-masing dimensi program K3 dan produktivitas kerja termasuk dalam kategori baik dengan rata-rata minimal 4,23 dan maksimal 4,37. Sama halnya, kinerja K3 perusahaan divisi proyek sangat baik jika dilihat dari piramida insiden dari tahun 2017 hingga 2020 terjadi penurunan yang signifikan dan meningkatnya pelaporan bahaya risko dan pelaporan dan investigasi nearmiss.

Berdasarkan hasil Path Analysis beberapa variabel program K3 berpengaruh secara signifikan dan positif secara bersama-sama terhadap varibel produktivitas kerja. Hal ini terbuki dengan hasil perhitungan SPSS yang menginterpretasikan bahwa nilai Sig. $<0,05$ dengan keputusan Ho ditolak. Sehingga Ha diterima, dan disimpulkan bahwa pelaksanaan program K3 berpengaruh terhadap produktivitas kerja. Dengan terbuktinya hasil penelitian yaitu pengaruh positif secara bersama-sama program K3 terhadap produktivitas, maka direkomendasikan perusahaan mempertimbangkan atau mempertahankan serta memprioritaskan biaya K3 (Safety Cost atau safety device) berdasarkan rekomendasi kontrol manajemen risiko (JSA \&HIRADC) guna untuk meningkatkan produktivitas kerja yang lebih optimal. Sementara Manajemen tekanan dan pencegahan kecelakaan berkontribusi secara positif namun tidak signifikan atau mempunyai nilai koefisien yang paling rendah, sehingga peneliti merekomendasikan untuk meningkatkan atau memperbaiki seta evaluasi konsep program K3 yang sudah ada.

\section{DAFTAR PUSTAKA}

Eyiah, A. K., Kheni, N. A., \& Quartey, P. D. (2019). An assessment of occupational health and safety regulations in Ghana: A study of the construction industry. Journal of Building Construction and Planning Research, 7(2), 11-31.

Kani, B. R., Mandagi, R. J., p Rantung, J., \& Malingkas, G. Y. (2013). keselamatan dan kesehatan kerja pada pelaksanaan proyek konstruksi (studi kasus: proyek PT. trakindo utama). Jurnal Sipil Statik, 1(6).

Pangkey, F., Malingkas, G. Y., \& Walangitan, D. R. O. (2012). Penerapan sistem manajemen keselamatan dan kesehatan kerja (smk3) pada proyek konstruksi di indonesia (Studi kasus: pembangunan jembatan Dr. Ir. Soekarno-Manado). Jurnal IImiah Media Engineering, 2(2). 100-113.

Hameed, A, dan Amjad, S. (2009): Impact of office design on emplyees productivity A casestudy of banking organizations of Abbottabad, Pakistan. Journal of Public Affairs, Administration and Management, 3(1), 1-13. 
Jackson., Randall, S., Schuler., \& Steve, W. (2010). Managing human resources edisi kesepuluh. Jakarta: Salemba Empat.

Katsuro, P., Gadzirayi, C. T., Taruwona, M., \& Mupararano, S. (2010). Impact of occupational health and safety on worker productivity: A case of Zimbabwe food industry. African Journal of Business Management, 4(13), 2644-2651.

Purwanti, L. D., \& Al Musadieq, M. (2017). Pengaruh keselamatan dan kesehatan kerja terhadap kualitas kehidupan kerja dan produktivitas kerja (studi pada karyawan divisi operasiddan pemeliharannpt pembangkitan Jawa Bali (Pjb) unit pembangkitan Paiton). Jurnal Administrasi Bisnis, 44(1), 118-126.

Yiu, N. S., Chan, D. W., Sze, N. N., Shan, M., \& Chan, A. P. (2019). Implementation of safety management system for improving construction safety performance: a structural equation modelling approach. Buildings, 9(4), 89.

OSHA. (2016). Recommended practices for safety \& health programs in construction. Occupational Safety and Health Administration

Peraturan Pemerintah No. 50 Tahun 2012 tentang Penerapan sistem manajemen keselamatan dan kesehatan kerja

Peraturan Menteri Pekerjaan Umum dan Perumahan Rakyat No.2/PRT/M/2018 tentang Perubahan atas peraturan menteri pekerjaan umum nomor 05/PRT/M/2014 tentang Pedoman SMK3 konstruksi bidang pekerjaan umum.

Choudhry, R. M., Fang, D., \& Ahmed, S. M. (2008). Safety management in construction: Best practices in Hong Kong. Journal of professional issues in engineering education and practice, 134(1), 20-32.

El-Nagar, R., Hosny, H., \& Askar, H. S. (2015). Development of a safety performance index for construction projects in Egypt. American Journal of Civil Engineering and Architecture, 3(5), 182-192.

Chinda, T., Techapreechawong, S., \& Teeraprasert, S. (2012). An investigation of relationships between employees' safety and productivity. In Proceedings of the 3rd International Conference on Engineering, Project and Production Management (EPPM2012) (pp. 10-11).

Tingshen, Z., Seyed, E.K., Wen, L, dan Miao, Z. (2018): Safety Management Implementation in Construction Sites, School of Civil Engineering \& Mechanics. Wuhan, China : Huazhong University of Science and Technology

Saeed, Y. S. (2017). Safety management in construction projects. Journal of Duhok University, 20(1), 546-560.

Messah, Y. A., Bella, R. A., \& Lolo, T. A. (2015). Solusi pencegahan kecelakaan kerja dalam pelaksanaan konstruksi gedung di kota Kupang. Jurnal Teknik Sipil, 4(2), 147-158. 